\title{
Borderline tuberculoid leprosy with type 1/reversal reaction
}

\author{
Supriya Khardenavis, ${ }^{1}$ Anirudda Deshpande ${ }^{2}$
}

'JJM Medical College, Davanagere, Karnataka, India ${ }^{2}$ Department of Neurology, Kasturba Medical College Hospital, Manipal, Karnataka, India

\section{Correspondence to}

Dr Anirudda Jaikrishna Deshpande, dr.aniruddha. deshpande@gmail.com

\section{DESCRIPTION}

Leprosy remains a common cause of peripheral neuropathy in the Indian subcontinent. ${ }^{1}$ Clinical manifestations include skin lesions, peripheral nerve involvement in the form of numbness or weakness or painless non-healing ulcers in anaesthetic hands or feet. ' 'Type 1' reactions are typically seen in patients with an unstable immunological response. They may occur in

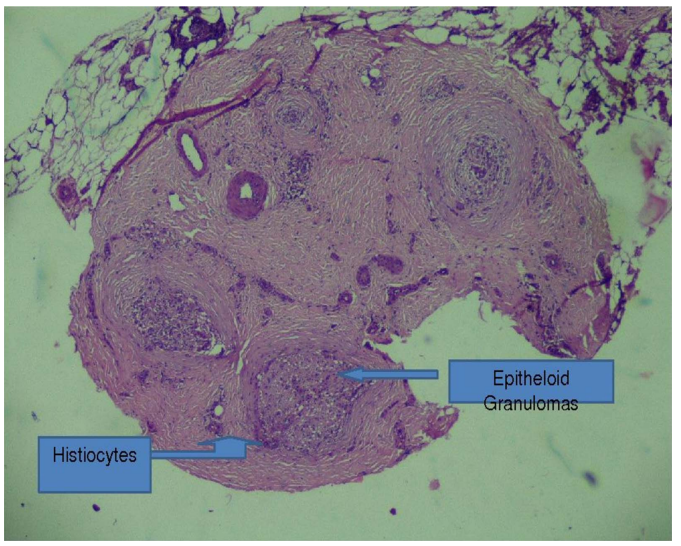

Figure 1 Histopathology slide of nerve biopsy showing histiocytes and epithelioid cells (marked with pointed arrows; H\&E $\times 40$ ).

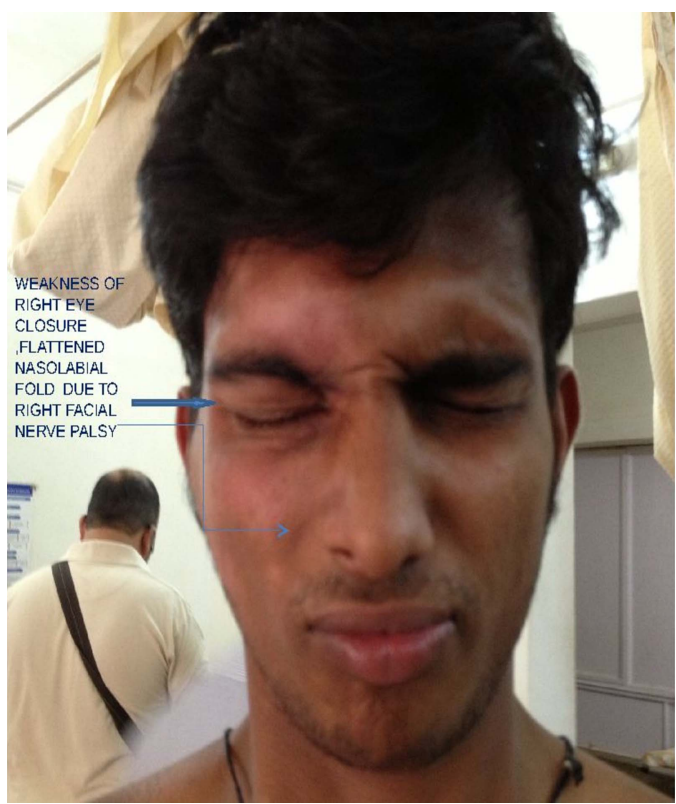

Figure 2 Post-therapy clinical photograph (3 weeks after initiation of multidrug therapy). Right lower motor neuron facial palsy depicted by weak eye closure, flattened right naso labial fold. patients with borderline tuberculoid (BT), midborderline and borderline lepromatous leprosy and present as erythema and oedema of existing skin lesions, eruption of fresh lesions, inflamed nerves and sensory or motor symptoms. ${ }^{3}$ Lesions in BT leprosy are like tuberculoid leprosy but smaller and more numerous with less nerve enlargement. This form may persist, revert to tuberculoid leprosy or may advance to other forms. ${ }^{4}$

We present images of a 24 -year-old man diagnosed with BT leprosy on right greater auricular nerve biopsy (figure 1). He presented with classical clinical features including thickened inflamed nerves, right lower motor neuron-type facial nerve palsy (figure 2), painless non-healing ulcers on hands and feet (figure 3), clawing of hands (figure 4) and hypopigmented skin patches. Within a week of starting multidrug therapy (rifampicin, dapsone and clofazimine) he developed an erythematous, painful rash on the right side of the face, a manifestation of type 1

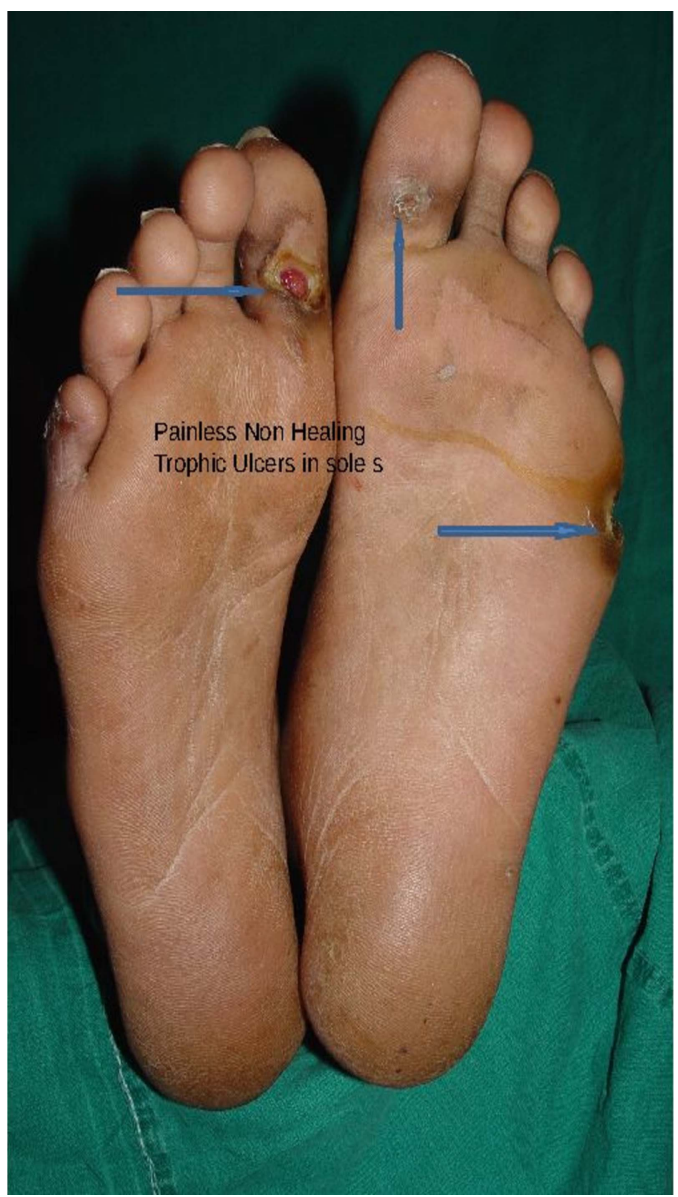

Figure 3 Pretherapy clinical photograph showing painless, non-healing trophic ulcers in feet. 


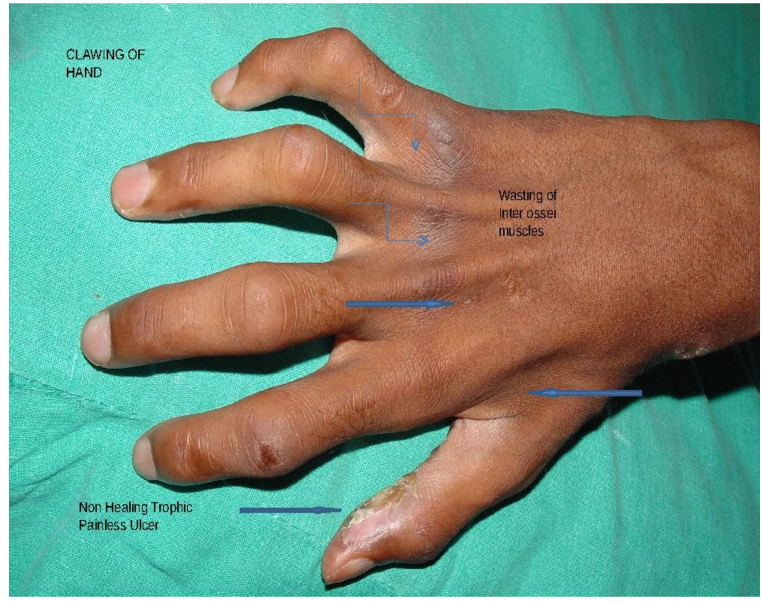

Figure 4 Pretherapy clinical photograph showing clawing of hands, wasting of interossei muscles, painless non-healing ulcers on hand.

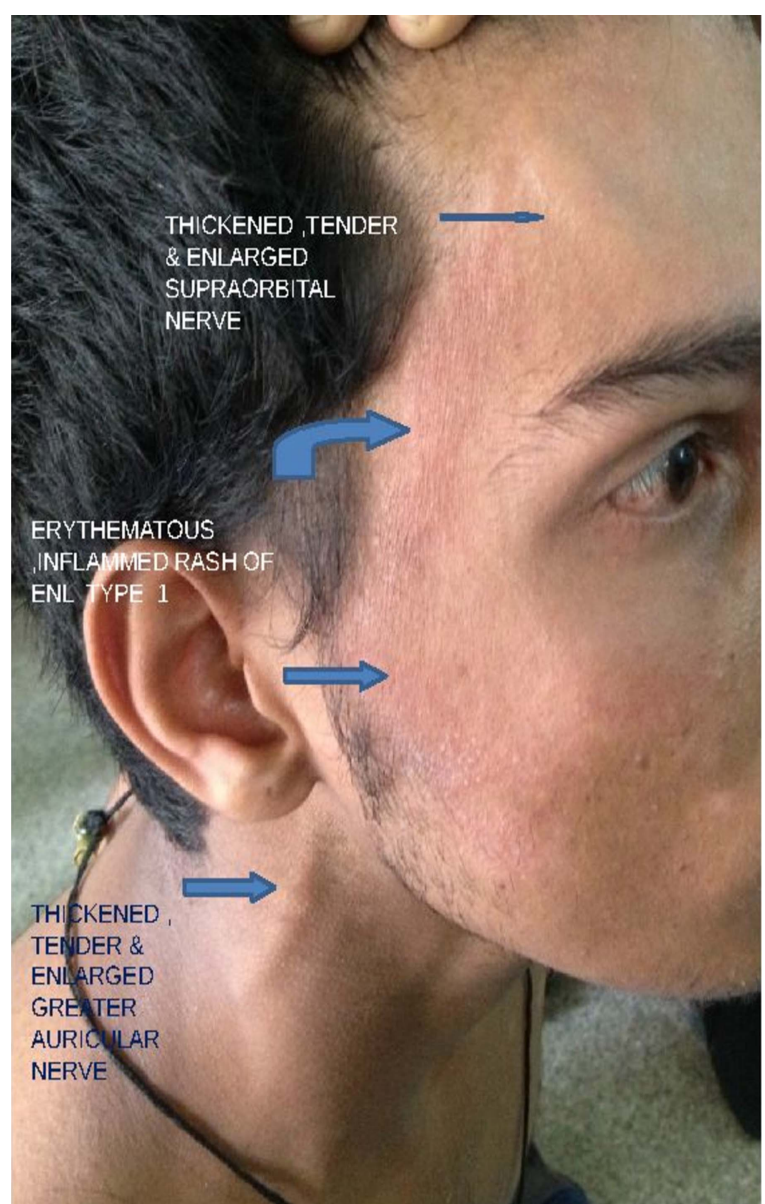

Figure 5 Post-therapy clinical photograph (3 weeks after initiation of multidrug therapy) showing thickened inflamed tender supraorbital (right) and greater auricular nerve (right), with red, inflammed rash on the right side of the face seen in type 1 reversal reaction.

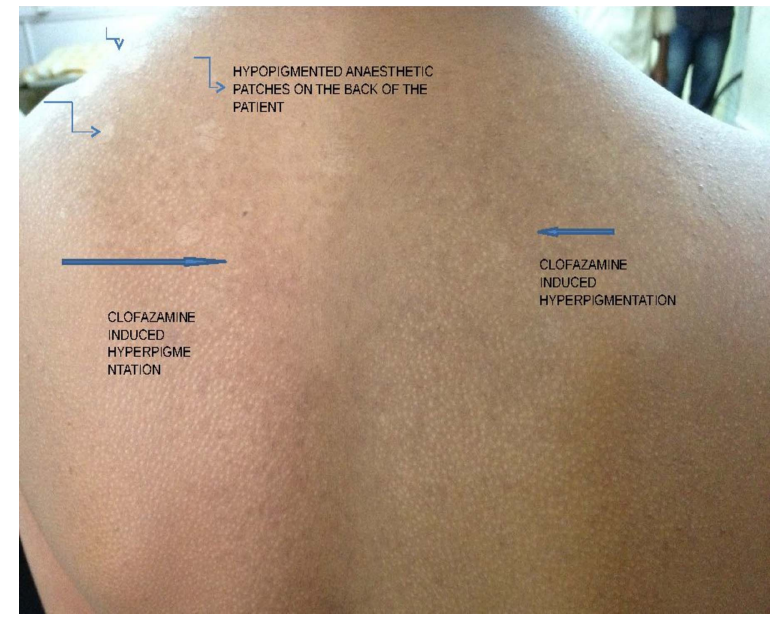

Figure 6 Post-therapy clinical photograph (3 weeks after initiation of multidrug therapy) showing clofazimine-induced hyperpigmentation on the back.

reversal reaction (figure 5). Over the next few follow-up visits, we also noticed hyperpigmentation of skin on his back, most probably clofazimine-induced (figure 6).

These classical images of leprosy are a reminder to medical students and practicing physicians of the importance of maintaining diagnostic skills in recognising this ancient disease.

\section{Learning points}

- Leprosy causes painless, non-healing ulcers, clawing of hands, hypopigmented anaesthetic patches, thickened nerves and lower motor neuron facial palsy.

- Type 1 reversal reaction can present as lesions of the skin, eruption of newer skin lesions, inflamed nerves and sensory or motor symptoms.

- Antileprosy drug clofazimine has hyperpigmentation as a major cosmetic side effect.

Contributors SJK has contributed substantially to the conception design of the work; the acquisition, analysis or interpretation of data for the work contributed by AJD and SJK. AJD has contributed in drafting the work or revising it critically for important intellectual content; and also final approval of the version to be published.

Competing interests None.

Patient consent Obtained.

Provenance and peer review Not commissioned; externally peer reviewed.

\section{REFERENCES}

1 Bhat RM, Prakash C. Leprosy: an overview of pathophysiology. Interdiscip Perspect Infect Dis 2012:2012:6.

2 Saonere JA. Leprosy: an overview. J Infect Dis Immun 2011;3:233-43.

3 Walker SL, Lockwood DNJ. The clinical and immunological features of leprosy. Br Med Bull 2006:77-78:103-21.

4 Obi JC, Imianvan AA. Analysis, diagnosis and prognosis of leprosy utilising fuzzy classifier. Bayero J Pure Appl Sci 2012;5:149-54. 
Copyright 2014 BMJ Publishing Group. All rights reserved. For permission to reuse any of this content visit http://group.bmj.com/group/rights-licensing/permissions.

BMJ Case Report Fellows may re-use this article for personal use and teaching without any further permission.

Become a Fellow of BMJ Case Reports today and you can:

- Submit as many cases as you like

- Enjoy fast sympathetic peer review and rapid publication of accepted articles

- Access all the published articles

- Re-use any of the published material for personal use and teaching without further permission

For information on Institutional Fellowships contact consortiasales@bmjgroup.com

Visit casereports.bmj.com for more articles like this and to become a Fellow 